\title{
PISA - Hvað svo? Nokkur leiðarstef um innleiðingu menntaumbóta
}

\author{
Anna Kristín Sigurðardóttir
}
Abstract
Um höfund
About the author
- Heimildir

Niðurstöður PISA 2018 verða gerðar opinberar í byrjun desember 2019. Af pví tilefni má búast við víðtækri umræðu í samfélaginu um menntamál og um gæði íslenska menntakerfisins. Dessari grein er ætlað að vera innlegg í pá umræðu og pá einkum um æskileg viðbrögð eða aðgerðir til að bæta menntun íslenskra barna og ungmenna. Dregin er saman nýleg pekking um farsælar menntaumbætur og reynt að varpa ljósi á hvaða hagnýtu pýđingu hún kann að hafa fyrir umbótastarf hér á landi. Á grunni peirrar pekkingar eru sett fram sjö leiðarstef sem gagnlegt er að hafa til hliðsjónar við innleiðingu umbótastarfs, pau eru: Nám og kennsla í brennidepli; aðstæðubundnar aðgerðir; samstarfsmiðuð nálgun og samvirkni; fagleg forysta, pekking og hæfni; menntarannsóknir; fjölskyldur og samfélag; og jöfnuður á öllum stigum kerfisins. Til nánari útskýringar er sett fram eitt dæmi um umbætur sem byggja á pessum leiðarstefjum.

Efnisorð: Menntaumbætur, innleiðing menntastefnu, samvirkni, lærdómssamfélag, menntarannsóknir, gæði menntakerfa

\section{Inngangur}

Niðurstöður PISA-könnunarinnar eru birtar á priggja ára fresti. Í hvert sinn verða miklar og heitar umræður í samfélaginu um menntamál og um gæði eða skort á gæðum í íslensku skólastarfi. Oftast er umræðan málefnaleg en stundum einkennist hún af upphrópunum, leitað er sökudólga eða einföldum lausnum skellt fram. Eftir skamman tíma hljóðnar umræðan og liggur jafnvel í dvala par til niðurstöður næstu PISA-könnunar eru birtar, í ljós kemur að pær ráðstafanir sem gripið var til hafa ekki dugað og enn og aftur lendir Ísland of neðarlega á listanum. Detta gerist hér á landi á Íslandi og í mörgum öđrum löndum.

Spurningar um gæði íslensks menntakerfis eru háværar á tímamótum eins og pessum. Slíkar spurningar ættu reyndar að vera stöðugt til umræðu á meðal allra peirra sem láta sig menntamál varða. Mat á gæðum menntunar ræðst óhjákvæmilega af peim sjónarhóli sem horft er frá hverju sinni. Markmið menntunar eru ólík á hverjum tíma og stað, pau mótast meðal annars af pólitískum áherslum ásamt menningar- og sögulegu samhengi. Pau geta beinst að ólíkum páttum, svo sem að ná betri árangri á prófum, að efla samkeppnishæfni pjóđarinnar á alljóđavettvangi, að undirbúa börn og ungmenni undir pá framtíð sem bíður peirra í einkalífi, námi og atvinnulífi eða að búa börn og ungmenni undir að takast á við samfélagslegar áskoranir. Enn aðrir vilja líta á skólann sem samfélag í sjálfu sér án tillits til pess sem kemur á undan eða eftir. Út frá pví sjónarhorni ber að skapa samfélag jöfnuðar og jákvæðra samskipta, par sem áhersla er á að hver og einn njóti 
hæfileika sinna á eigin forsendum. Forde og McMahon (2019) eru meðal peirra sem telja að markmið menntunar ættu fyrst og fremst að beinast að almannaheill, að pví sem er gott fyrir samfélagið fremur en að efnahagslegum gæðum eins og auknum hagvexti. Kristján Kristjánsson heimspekingur (2019) tekur undir pað og talar um farsæld sem markmið menntunar, par sem hann vísar bæði til farsældar einstaklingsins og samfélagsins.

Bent hefur verið á af Efnahags- og framfarastofnuninni (OECD, 2012) að árangursríkustu menntakerfi heims eru pau sem ná að sameina gæði og jöfnuð. Ýmsir fræðimenn hafa síðan varpað ljósi á hvernig ójöfnuður á Norðurlöndum hefur aukist (Dovemark o.fl., 2018), sem getur haft neikvæð áhrif á námsmöguleika og árangur barna. Norrænt öndvegissetur um jöfnuð og réttlæti í menntun birti nýlega stefnumið byggð á rannsóknum fjölda norrænna vísindamanna (JustEd, 2018). Dar er m.a. lagt til að stjórnvöld leiti allra leiða til að jafna aðgang að skólum og menntun, svo að í skólum sé unnið gegn ójöfnuði og jöðrun og í skólastofunni sé leitað jafnvægis milli umfjöllunar námsefnis og frumkvæðis og pátttöku nemenda. Dessi stefnuviðmið eru góður grunnur fyrir íslensk stjórnvöld, einkum í ljósi pess að vísbendingar eru um aukinn ójöfnuð meðal barna hér á landi (Berglind Rós Magnúsdóttir og Auður Magndís Auðardóttir, 2019) auk pess sem of stór hluti barna á Íslandi býr við fátækt (Kolbeinn H. Stefánsson, 2019) sem getur haft neikvæð áhrif á möguleika peirra til proska og menntunar.

Kennarinn hefur löngum verið í brennidepli í umræðu um gæði menntunar. Í pekktri McKinseyskýrslu sem kom út fyrir meira en áratug (Barber og Mourshed, 2007) er mikilvægt hlutverk kennarans áréttað í tengslum við gæði menntakerfis. Í samræmi við petta hefur pað orðið eins konar prástef í umræðunni að gæði menntakerfa verði ekki meiri en gæði peirra kennara sem innan pess starfa. Asia Society, Centre for Global Education (2011) sem er alpjóðlegur samráðsvettvangur um menntamál leggur aftur á móti áherslu á að ekki sé síður mikilvægt að gera sér grein fyrir pví að gæði kennara verða ekki meiri en gæði pess menntakerfis sem peir starfa innan. Darling-Hammond (2013) bendir reyndar réttilega á að frekar ætti að tala um gæði kennslu eða kennsluhátta fremur en kennara, meðal annars vegna pess að margir kennarar koma að menntun hvers og eins nemanda.

Hér að framan hefur verið stiklað á stóru um hin ólíku markmið menntunar og gæði menntakerfa. Í pessari grein er sjónum fyrst og fremst beint að innleiðingu menntaumbóta fremur en að stefnumótun eða inntaki menntunar. Tilgangurinn er að leggja af mörkum inn í pá umræðu sem óhjákvæmilega fylgir í kjölfar kynningar á niðurstöðum PISA 2018 með pví að draga saman nýlega pekkingu á farsælum menntaumbótum. Einkum er reynt að varpa ljósi á hvaða hagnýtu pýðingu hún kann að hafa fyrir umbótastarf hér á landi. Í pví skyni eru sett fram sjö leiðarstef sem gagnlegt gæti verið að hafa til hliðsjónar pegar teknar eru ákvarðanir um menntaumbætur á landsvísu, í einstökum sveitarfélögum eða í skólum. Dessi leiðarstef byggja á hluta peirrar pekkingar sem nokkurra áratuga rannsóknir á farsælum menntaumbótum hafa leitt í ljós og gerð er grein fyrir í stuttu máli hér á eftir.

\section{Farsæl innleiðing menntaumbóta}

Pó pekkingu á pví hvað gæti mögulega leitt til farsælla menntaumbóta hafi fleygt fram á síðasta áratug, vantar enn talsvert upp á skilning á pví hvernig skuli bera sig að við innleiðingu til að ná peim árangri sem stefnt var að. Niðurstöður rannsókna hafa gjarna verið misvísandi auk pess sem tíðarandi og pólitískar áherslur á hverjum tíma hafa áhrif á hvernig niðurstöður rannsókna eru túlkaðar. Баð er pó almennt viðurkennt meðal fræðimanna á pessu sviði að einfaldar lausnir duga ekki. Skólar eru flóknar stofnanir og margir pættir hafa áhrif. Fyrir pessu parf að bera virðingu pegar aðferðir við stefnumótun og innleiðingu eru ákvarðaðar. Hopkins, Stringfield, Harris, Stoll og Mackay (2014) hafa tekið saman gagnlegt yfirlit um próun pekkingar á skóla- og menntaumbótum í hinum vestræna heimi, síðustu fjóra til fimm áratugi eða svo. Pau skilgreina fimm skref sem skarast í tíma og byggja hvert á öðru. Skrefin vísa til pess hvernig umræðan hefur færst frá pví að leggja höfuðáherslu á mikilvægi pess að skilja menningu hvers skóla á 7 . og 8. 
áratug síðustu aldar (sjá t.d. Sarason, 1971), yfir í áherslu á yfirgripsmikil umbótaverkefni með stífum árangursmælingum í kringum síðustu aldamót. Að peirra mati hafa pessar rannsóknir nú leitt umræðuna í átt að heiltækri nálgun par sem megináhersla er á samvirkni í öllu kerfinu, faglegt nám og að styrkja innri hæfni til stöðugra umbóta.

Á árum áður kepptust fræðimenn við að greina einkenni árangursríkra skóla (t.d. Mortimore, Sammons, Stoll, Lewis og Ecob, 1988; Teddlie og Stringfield, 1993) og til urðu listar yfir fjölmörg atriði sem beina skyldi sjónum að í umbótastarfi. Framlag pessara rannsókna var mikilsvert, niðurstöður peirra tóku m.a. af allan vafa um að skólinn hefur áhrif á árangur og vellíðan nemenda sem efast hafði verið um fram að pessum tíma. Með frekari rannsóknum og aukinni pekkingu varð pó ljóst að slíkir listar reyndust ekki gagnlegir leiðarvísar, hvorki fyrir skóla né menntayfirvöld, verkefnið er flóknara en svo. Nú er ljóst að peir pættir sem höfðu jákvæð tengsl við árangur, margir hverjir vel pekktir en aðrir nýlega uppgötvaðir sem áhrifavaldar, eru innbyrðis háðir, peir vinna saman með mismunandi hætti eftir aðstæðum á hverjum stað. Við slíkar aðstæður verður umbótastarf flókið, margir pættir hafa áhrif sem erfitt getur verið að sjá fyrir og oft verður útkoman allt önnur en sú sem lagt var af stað með í upphafi. Aðferðir, sem hafa reynst árangursríkar á einum stað, virka ef til vill ekki í öðrum aðstæðum. Parna spila félagslegar og menningarbundnar aðstæður inn í.

Blossing, Nyen, Söderström and Tønder (2015), sem skoðuðu norska skóla, taka undir með Hopkins og félögum (2014) um mikilvægi samvirkni í kerfinu. Dau bæta við að misræmi milli ytri krafna frá samfélaginu eða menntayfirvöldum og innri parfar í skólum, meðal annars fyrir stuðning, geti hamlað jákvæðum árangri umbótastarfs og par með bættum námsárangri. Skóli er hluti af samfélagi, hannhefur áhrif á umhverfi sitt og verður að sama skapi fyrir áhrifum af umhverfinu. Breytingar á einum hluta kerfisins hafa óhjákvæmilega áhrif á aðra hluta pess. Dví er pörf á heiltækri nálgun, að beina sjónum að kerfinu sem heild, að einstaklingum, bekknum, skólanum, sveitarfélaginu og menntakerfinu á landsvísu, par sem tekið er mið af aðstæðum á hverjum stað.

Rétt er að ítreka að með áherslu á samvirkni og heiltæka nálgun er ekki verið að kalla eftir aukinni miðstýringu, með skýrri stefnumótun „ofan frá“ sem nákvæmlega er fylgt eftir inn á neðri stig kerfisins. Slík nálgun er vissulega valkostur en hefur ekki skilað tilætluðum árangri (Hargreaves og Shirley, 2013; Tyack og Cuban, 1995; Labaree, 2010) og er í raun ólýðræðisleg par sem völd eiga pað til að safnast á fárra hendur (Trippestad, 2017) og gæti grafið undan fagmennsku kennara og stjórnenda (Fullan, 2016). Samkvæmt Robinson, Bendikson, McNaughton,Wilson og Zhu (2017) dregur pessi nálgun úr pörf fyrir samskipti og samræður sem nauðsynlegar eru til að skapa sameiginlegan skilning á markmiðum og uppbyggingu pekkingar og par með árangursríku umbótastarfi. Að mati Robinson (2018) teljast breytingar einungis til umbótaverkefna ef pær leiða til betri námsárangurs eða vellíðunar nemenda, sem aftur beinir sjónum að mikilvægi bess að styrkja pað starf sem fer fram í öllum skólastofum landsins, kennsluháttum og samskiptum. Hún ítrekar pó að öll viðleitni til að efla pekkingu kennara og próa kennsluhætti sé ekki líkleg til að skila tilætluðum árangri nema að umhverfi og skipulag í skólanum sem heild styðji við pá starfshætti sem á að innleiða.

Nú er ekki lengur horft á lista yfir einkenni árangursríkra skóla eins og var vinsælt á árum áđur, né heldur á einstakar kennsluaðferðir sem teljast hafa verið sannreyndar við einhverjar ákveðnar aðstæður. Frekar horfa fræðimenn til pátta sem mögulega geta stuðlað að sjálfbærum menntaumbótum, p.e. umbótum sem hæfa pörfum hvers samfélags og hafa jákvæð áhrif til lengri tíma litið, umbætur sem styrkja innri hæfni og stuðla að faglegu námi sem leiðir fólk áfram yfir á næsta stig í umbótaferlinu. Hér er um að ræða pætti eins og rannsóknarmiðaða starfshætti par sem kennarinn sjálfur hefur eftirlit með áhrifum eigin kennsluhátta, faglegt samstarf, faglegt nám og markvissa nýtingu á áreiðanlegum upplýsingum til að undirbyggja ákvarðanatöku á öllum stigum (Ash og Hodge, 2016; Forde og McMahon, 2019; Fullan, 2016; Hargreaves og Shirley, 2013; Robinson, 2018; Stoll og Louis, 2007). Breytingastarf í pá veru sem lýst er hér að 
framan má kalla sjálfbærar menntaumbætur par sem allt kerfið er undir, umbætur sem byggja á sameiginlegri sýn um gæði og tilgang menntunar og byggja upp hæfni bæði hjá einstaklingum og stofnunum til að takast á við stöðugar umbætur.

Í pessu sambandi er mikilvægt að byggja upp traust og efla fagmennsku á öllum stigum. Í pví skyni ætti að skipta út ytri ábyrgðarskyldu par sem kröfur eru gerðar um útkomu fyrir innri ábyrgðarskyldu par sem krafist er fagmennsku (Fullan, 2016; Gunter, Grimaldi, Hall og Serpieri, 2016; Hargreaves og Fullan, 2012; Hatch, 2013). Hætta er talin á að of miklar kröfur um útkomu á prófum grafi undan trausti par sem fagfólk fær ekki svigrúm til að próa starfshætti í pær áttir sem pað telur árangursríkast. Hér er átt við pað fagfólk sem vinnur í daglegum tengslum við nemendur skólanna og stendur undir gæðum hvers menntakerfis. Sem dæmi um ólíka nálgun menntayfirvalda nefna Fullan og Quinn (2016) tvær leiðir sem fara má pegar ljóst er að breyta parf vinnubrögðum til að bæta árangur. Báðar pessar leiðir eru vel pekktar og oft nýttar, önnur reiðir sig á ytri ábyrgðarskyldu en hin á innri ábyrgðarskyldu. Annars vegar geta yfirvöld (á hvaða stigi sem er) ákveðið að best sé að fá utanaðkomandi aðila til að taka út stöðuna og gera áætlun um aðgerðir. Hins vegar gætu pau ákveðið að setja saman hóp eða hópa fagfólks, kennara og fleiri, til að fara yfir stöðuna og setja upp áætlun um aðgerðir. Síðarnefnda leiðin er mun líklegri til að gefa skilaboð um traust til fagfólksins á sama tíma og hún styrkir fagmennsku hópsins til lengri tíma (Robinson, 2018) og er pví líklegri til að byggja upp innri pekkingu og hæfni til að takast á við næsta umbótaverkefni.

Í köflunum hér á eftir er fjallað nánar um nokkra pá pætti sem taldir eru hafa hvað mest jákvæð áhrif á innleiðingu umbóta. Deir eru: Skóli sem lærdómssamfélag, að nýta rannsóknir og upplýsingar í daglegu skólastarfi og stefnumótun, faglegt nám og starfspróun, og að lokum fagleg tengsl og samstarf.

\section{Skóli sem lærdómssamfélag}

Kenningar um sjálfbæra skólapróun eða menntaumbætur endurspeglast vel í hugmyndum um skólann sem lærdómssamfélag sem hafa verið vinsælar í skólaumræðu bæði hér heima og erlendis á undanförnum áratug (Berglind Gísladóttir, Auður Pálsdóttir, Anna Kristín Sigurðardóttir og Birna Svanbjörnsdóttir, bíður birtingar; Dogan og Adams, 2018; Stoll og Louis, 2007), par sem gert er ráð fyrir að kennarar ígrundi saman árangur og afleiðingar mismunandi kennsluaðferða á grundvelli áreiðanlegra upplýsinga. Í lærdómssamfélagi er slík ígrundun eðlilegur hluti af daglegu starfi kennara og stjórnenda. Í samræmi við petta er rætt um faglegt lærdómssamfélag sem leið til að styrkja innri hæfni til stöðugra breytinga (Fullan, 2016; Hargreaves og Fullan, 2012; Harris og Jones, 2010) og til að stuðla að faglegu námi eða starfspróun (Muijs o.fl., 2014; Stoll, Harris og Handscomb, 2012).

Pegar rætt er um skóla sem faglegt lærdómssamfélag er vísað til einkenna í menningu og skipulagi sem hvetja til pess að starfsmenn læri hver af öðrum og hver með öðrum í peim einlæga ásetningi að bæta frammistöðu allra nemenda skólans.

Lærdómssamfélag er hópur fólks sem deilir sameiginlegum áhuga og sýn á nám, vinnur saman, styður hvert annað og leitar sameiginlegra leiða til að greina starfshætti sína, bæta pá og innleiða nýja sem geta stuðlað að betri árangri nemenda. (Stoll, Bolam, McMahon, Wallace og Thomas, 2006; pýð. Anna Kristín Sigurðardóttir, 2013, bls. 37)

Faglegt lærdómssamfélag hefur í allmörgum rannsóknum sýnt sig hafa jákvæð áhrif á árangur nemenda í gegnum jákvæd áhrif á pekkingu, hæfni og viðhorf kennara (Dogan og Adams, 2018; Lomos, Hofman og Bosker, 2011; Anna Kristín Sigurðardóttir, 2010; Burns o.fl., 2017), pótt enn sé mörgum spurningum ósvarad (t.d. Hairon, Goh, Chua and Wang, 2017; Lomos o.fl., 2011). Dótt hugmyndir um skólann sem lærdómssamfélag séu vissulega lofandi um farsælt umbótastarf er ekki prautalaust að koma pví í framkvæmd. Fullan (2016) bendir meðal annars 
á hættuna á að bæði skilningur og par af leiðandi aðgerðir verði of yfirborðslegar, skili pví ekki peim árangri sem lagt var upp með og verði of snemma afgreiddar sem eitthvað sem engu skilar. Hann tekur par undir með McLaughlin og Talbert (2001) og Harris (2013) sem bentu á að samstarf sem ekki hefði í för með sér faglegt nám gæeti verið tímasóun og hefði ekkert með lærdómssamfélag að gera. Faglegt lærdómssamfélag getur verið mælikvarði á hversu reiðubúið viðkomandi skólasamfélag er til að taka pátt í umbótastarfi. Dar sem pað er sterkt má búast við að innleiðing umbóta gangi betur.

\section{Að nýta rannsóknir og upplýsingar í daglegu skólastarfi og stefnumótun}

Að nýta gögn og niðurstöður rannsókna sem grundvöll ákvarðanatöku í skólastarfi er sá páttur sem getur haft hvað mest að segja um árangur umbótastarfs til lengri tíma litið (Cowan, Joyner og Beckwith, 2012; Fullan, 2016; Schildkamp, Ehren og Lai, 2012; Stoll o.fl., 2012). Detta er pó ekki eins einfalt ferli og pað kann að líta út fyrir í fyrstu og mörg álitamál koma fram. Dað er til að mynda ekki einhugur um hvaða rannsóknir eða gögn séu gild, áreiðanleg og viðeigandi í hverju tilviki né heldur hvort eða hvaða niðurstöður gefi vísbendingar um hvernig skuli bregðast við. Sífellt parf að vega og meta hvenær niðurstöður rannsókna geti talist vera almenn pekking eða sannindi sem taka beri mið af við stefnumótun og skipulag daglegs skólastarfs. Síðast en ekki síst má nefna að gögn gefa upplýsingar um stöðuna en ekki hvað eigi að gera eins og Jón Torfi Jónasson (2016) bendir réttilega á.

Spillane (2012) er einn peirra sem hefur varað við pví að litið sé svo á að notkun á niðurstöðum rannsókna leiði óhjákvæmilega og nánast sjálfkrafa til betra eða árangursríkara starfs. Svo sé alls ekki, niðurstöður rannsókna geti verið mistúlkaðar, oftúlkaðar eða ekki viðeigandi í viðkomandi aðstæðum. Steiner-Khamsi (2013) og Harris (2012) taka undir petta og gagnrýna að ákveðnar aðferðir séu kynntar sem gagnreyndar (e. best practice) og séu í krafti pess teknar upp gagnrýnislaust í aðstæðum sem jafnvel eru menningarlega og félagslega gerólíkar peim aðstæðum sem pær voru prófaðar. Gagnsemi peirra veltur á pví hvort pær hæfa aðstæðum og að gert hafi verið ráð fyrir virkri pátttöku kennara og annarra starfsmanna við að safna, greina og túlka ásamt pví að vega og meta með gagnrýnum hætti afleiðingar fyrir daglegt starf. Nýting á áreiðanlegum upplýsingum og niðurstöðum, sem grunni að ákvarðanatöku um stefnumótun og aðgerðir, er mikilvæg á öllum stigum menntakerfisins en gögn parf að meta og nýta af faglegri dómgreind og pekkingu.

Robinson og félagar (2017) leggja áherslu á að í hverjum skóla ætti að vera til skilgreint ferli um pað hvenær og hvernig gögn eru nýtt. Рað er í raun viðeigandi að nýta rannsóknargögn á öllum stigum umbótaferils, p.e. við að meta stöðuna, ákveða til hvaða aðgerða á að grípa og við að meta hvernig til tekst, bæði varðandi ferlið og lokaafurð (Anna Kristín Sigurðardóttir, Morris, Skoglund og Tudjman, 2018). Fyrsta skrefið, og ef til vill pað mikilvægasta, felur ekki einungis í sér að meta stöðuna eins og hún virðist vera heldur einnig að viðurkenna hana, leita skýringa en forðast afsakanir eða að leita sökudólga. Hargreaves og Shirley (2013) leggja til að gögn, mælingar og rannsóknarniðurstöður verði nýttar til að aðstoða kennara og stjórnendur við að ígrunda árangur og afleiðingar daglegra starfshátta fremur en að nýta pau til að stýra, umbuna eða refsa á grundvelli útkomu. Pannig muni stjórnvöld, bæði sveitarfélaga og ríkis, styrkja og efla fagmennsku kennara og stjórnenda í skólum og byggja upp traust. Nýleg íslensk rannsókn bendir reyndar til að íslenskir kennarar nýti gögn og upplýsingar að litlu leyti til að taka ákvarðanir um kennsluhætti (Snædís Valsdóttir, 2017).

Fyrir utan að vera nauðsynlegur páttur í umbótastarfi er pátttaka í rannsóknum og ígrundun á niðurstöðum farsæl leið til að stuðla að faglegu námi (Burns o.fl., 2017), sem er umfjöllunarefni næsta kafla. 
Faglegt nám og starfspróun

Niðurstöður PISA 2015 voru kynntar í byrjun desember 2016. Dann sama dag birtu Fullan og Hargreaves (2016) ráðleggingar í litlu hefti sem peir nefndu Bringing the profession back in. Dar árétta peir mikilvægi pess að efla og styrkja fagmennsku kennara og stjórnenda. Með pví vildu peir hafa áhrif á umræðuna um niðurstöður PISA og beina viðbrögðum í átt að fagmennsku og faglegu námi. Dessi áminning peirra félaga á jafn vel við nú á dögum og svo vel vill til að nýlega skilaði Samstarfsrád um starfspróun kennara og skólastjórnenda (Stjórnarrád Íslands og Menntaog menningarmálaráðuneytið, 2019) skýrslu til mennta- og menningarmálaráðherra par sem settar eru fram fjölmargar tillögur um stefnu, skipulag og aðgerðir til að efla faglegt nám kennara og stjórnenda.

Faglegt nám fer ekki einungis fram í formlegu námi og námskeiðum, pað parf einnig að vera skipulagt sem hluti af daglegu starfi og eru par margar leiðir færar. Má par nefna til dæmis rannsóknarkennslustund (e. lesson study), að eiga gagnrýninn vin (e. critical friend), jafningjahandleiðslu og fleira (sjá t.d. Murray, 2014; Wennergren, 2015). Í stóru próunarverkefni sem innleitt var á landsvísu í grunnskólum í Noregi (Ungdomstrinn í Utvikling, UiU) völdu margir kennarar að nota athuganir á kennslustundum samkennara sinna sem tæki til að ná árangri og stuðla pannig að faglegu námi bæði einstaklinga og heildarinnar. Kennarar vonuðust til pess að með pví myndu peir sjá sína eigin starfshætti í nýju ljósi sem myndi auðvelda peim að breyta peim. Í viðtölum við norska kennara (Jensvoll og Lekang, 2017; Grandemo, Holmen og Iversen, 2017) kom fram að peir töldu sig læra mikið um sína eigin kennsluhætti af pví að fylgjast með kennslu hjá samkennurum og fá pá til að fylgjast með kennslu hjá sér, einkum af samræðunum sem fylgdu á eftir. Pessi aðferð var pó ekki vandalaus, erfitt var að finna tíma og mörgum reyndist erfitt að ræða gagnrýnið og af dýpt um starfshætti hver annars. Traust og virðing voru einnig mikilvæg, til að mynda vildu kennarar helst að sá sem fylgdist með peim væri einhver sem hefði meiri pekkingu eða reynslu heldur en peir sjálfir. Kennarar sem tóku pátt töldu að peir hefðu orðið betur meðvitaðir um eigin starfshætti og próað betri samskipti við nemendur. Flestir voru pó ekki vissir um að peir hefðu raunverulega breytt starfsháttum beinlínis vegna pátttöku í verkefninu en töldu sig vissulega betur undir pað búna að breyta peim.

Раð er breið sátt um pað meðal fræðimanna á pessu sviði að fagleg starfspróun skili mun frekar tilætluðum árangri ef hún er skipulögð og framkvæmd í beinum tengslum við áherslur í skólastarfinu og pau umbótaverkefni sem í gangi eru hverju sinni. Boylan og Demack (2018) tóku saman fjögur atriði sem talin eru einkenna árangursríka starfspróun og stuðla að faglegu námi. Dau eru að áhrif kennara á aðstæður og innihald séu tryggð, að hún fari fram í tengslum við aðstæður og parfir kennara, að starfspróun nái yfir lengri tíma og að lokum að hún byggi á samstarfi. Skólastjórnendur eru lykilaðilar í pessu tilliti, peir hafa áhrif á bæði inntak og aðferðir starfspróunar (Buttram og Farley-Ripple, 2016; Forde og McMahon, 2019) og hvernig sameiginlegar ákvarðanir innan skólans eru teknar (Supopvitz og Tognatta, 2013). Deir eru leiðtogar í lærdómssamfélagi, pví er ekki síður mikilvægt að tryggja peim starfspróun við hæfi heldur en kennurum.

\section{Fagleg tengsl og samstarf}

Samstarf og samstarfsmenning hefur víðtækan ávinning fyrir umbótastarf í skólum eins og ljóst má vera af pví sem sagt hefur verið hér að framan. Skipulagt samstarf er pó ekki nægilegt til að stuðla að lærdómsmenningu ef ekki fylgir gagnrýnin samræða og ígrundun (Dogan og Adams, 2018; McLaughlin og Talbert, 2001). Fullan og Quinn (2016) taka undir petta og segja að samstarf samstarfsins vegna sé tímasóun ef pað hefur ekki í för með sér faglegt nám bæði fyrir einstaklinga og hópa og byggir pannig upp félagsauð skólans og kerfisins í heild. Anna Kristín Sigurðardóttir (2008) ályktaði að skilyrði fyrir slíku faglegu námi væru sameiginlegir hagsmunir peirra sem standa að samstarfinu. Pannig væru einstaklingarnir ekki einungis að miðla eða ráðfæra sig hver við annan heldur væru peir sameiginlega að leita betri og árangursríkari leiða í námi og kennslu. 
Teymiskennsla er dæmi um samstarf par sem árangur starfsins ræðst af pví hversu vel tekst til í samstarfinu, sameiginlegir hagsmunir eru augljósir sem og sameiginleg ábyrgð. Ingvar Sigurgeirsson og Ingibjörg Kaldalóns (2017) drógu fram kosti teymiskennslu í rannsókn par sem pau báru saman svokallaða bekkjarkennsluskóla og teymiskennsluskóla. Pau komust meðal annars að pví að í skólunum sem rannsóknin tók til töldu kennarar að fagleg tengsl og fagleg umræða væri meiri í teymiskennsluskólunum heldur en hinum, kennarar voru ánægðari og töldu sig fá betri stuðning frá stjórnendum. Samskipti nemenda virtust einnig vera betri og ánægja peirra með kennsluna meiri. Dau bentu pó líka á að teymiskennsla hentaði ekki öllum og árangur hennar væri háður pví hvernig einstaklingum tækist að vinna saman.

Hér að framan hefur verið stiklað á stóru um pætti sem taldir eru hafa jákvæð áhrifá innleiðingu umbóta. Umfjöllunin er langt pví frá tæmandi en gefur vonandi hugmynd um æskilega nálgun 1 umbótastarfi. Til að mynda hefur áherslan fyrst og fremst beinst að skólastarfi en minna verið fjallað um mikilvæga pætti eins og fjölskylduna sem hefur mikil áhrif á árangur barna (Berglind Gísladóttir, Hans Haraldsson og Amalía Björnsdóttir, 2019) og almennar aðstæður barna í samfélaginu, s.s. fátækt og ójöfnuð. Leiðarstefin sem kynnt eru hér á eftir eru að stærstum hluta byggð á samantektinni hér að framan. Áđur en að pví kemur verður pó vikið nokkrum orðum að stöðunni hér á landi hvað varðar menntarannsóknir og pá sérstaklega rannsóknir á innleiðingu umbótaverkefna.

\section{Íslenskar menntarannsóknir og umbótaverkefni}

Íslenskum menntarannsóknum hefur vaxið fiskur um hrygg á undanförnum árum og áratugum, sem má meðal annars sjá í auknum fjölda birts efnis bæði á innlendum og erlendum vettvangi. Dær verða pó enn að teljast fremur veikar og flestar fremur smáar í sniðum, sérstaklega pær sem beinast að námi og kennslu. Umbótastarf í íslenskum skólum hefur verið umfangsmikið í gegnum tíðina á öllum stigum skólakerfisins, að frumkvæði stjórnvalda bæði á landsvísu og í sveitarfélögum, í einstökum skólum og skólastofum eða að frumkvæði kennara og stjórnenda. Sum pessara verkefna hafa eflaust skilað góðum árangri og önnur ekki, um pað er reyndar alltof lítið vitað. Lítið hefur verið um rannsóknir á árangri pessara verkefna og enn færri sem beinast að innleiðingarferlinu sjálfu. Eitt slíkt dæmi er pó nýleg rannsókn á innleiðingu Byrjendalæsis (Rúnar Sigpórsson og Gretar L. Marinósson, 2017), par sem aðferðafræði við innleiðingu breytinga er vel lýst. Margt í peirri aðferðafræði rímar vel við nýjustu kenningar um farsæla innleiðingu umbóta. Engu að síður kom í ljós að skólar stóðu misjafnlega að innleiðingu og framkvæmd verkefnisins og algengt var að ávinningur próunarstarfsins gengi til baka pegar formlegu innleiðingarferli lauk og stuðningur hætti. Slíkt er vel pekkt í sögu menntaumbóta (Fullan, 2016; Tyack og Cuban, 1995) og er gjarna vísad til pegar rætt er um sjálfbæra skólapróun.

Í pessari grein hefur verið bent á mikilvægi pess að umbótastarf hæfi aðstæðum á hverjum stað bæði að inntaki og aðferðum við innleiðingu. Í ljósi pess verður að telja mikilvægt að efla rannsóknir á innleiðingarferli og árangri umbótastarfs í íslenskum skólum, pótt vissulega megi margt og mikið læra af erlendum rannsóknum. Раð liggur pó fyrir talsverð, nýleg vitneskja um innra starf skóla hér á landi á öllum skólastigum og einnig eru dæmi um umfangsmikil skólapróunarverkefni, sem hefur verið vel stýrt og framvindan vel skráð. Dessi verkefni hafa pó oftar en ekki beinst að afmörkuðum sviðum en síður reynt að horfa vítt til að skilja hið flókna samspil ólíkra pátta. Saga skólapróunar á Íslandi er lauslega rakin í yfirgripsmiklu verki um albýðufræðslu á Íslandi (t.d. Rúnar Sigpórsson og Rósa Eggertsdóttir, 2008) og verður ekki endurtekin hér, en eitt og annað hefur pó bæst við á síðustu tíu árum.

Nýlegar og yfirgripsmiklar rannsóknarniðurstöður um starfshætti í grunnskólum (Gerður G. Óskarsdóttir, 2014) og í framhaldsskólum (Gerður G. Óskarsdóttir og rannsóknarhópur um starfshætti í framhaldsskólum 2018) liggja fyrir og eru mikilsvert framlag. Niðurstöður peirra gefa upplýsingar um stöđu á peim páttum sem rannsóknirnar náđu til, á peim tíma sem pær voru framkvæmdar, en beinast ekki að próun. Pessar rannsóknir mynda engu að síður dýrmætan grunn 
til að fylgjast með próun til lengri tíma. Dað sama má segja um umfangsmiklar rannsóknir um stöðu innflytjenda í íslensku skólakerfi (t.d. Hanna Ragnarsdóttir, 2016) og um íslenskukennslu í grunnskólum og framhaldsskólum (Kristján Jóhann Jóhannsson og Ásgrímur Angantýsson, 2018). Niðurstöður peirra beggja draga fram fjölmörg atriði í framkvæmd skólastarfs sem parfnast umbóta. Talsverð vitneskja liggur fyrir um nám yngri barna og starf í leikskólum af rannsóknum sem framkvæmdar hafa verið á vegum Rannsóknarstofu um menntun ungra barna. Fjölmörg önnur rannsóknar- og próunarverkefni mætti nefna hér sem hafa beinst að afmarkaðri páttum náms, kennslu eða líðan nemenda sem veita mikilvæga vitneskju en ekki er tækifæri til að fara í hér. Allar pessar rannsóknir draga fram upplýsingar um stöđu og auka skilning á viðfangsefninu. Hins vegar má spyrja hvort og pá hvernig niðurstöður hafa verið nýttar til umbóta í skólakerfinu, pað er tilfinning höfundar að par megi gera betur. Leita parf leiða til að styrkja fjölbreyttar menntarannsóknir sem varpa ljósi á íslenskt skólastarf en ekki síður ætti að styrkja pað ferli sem felur í sér að rýna í niðurstöður og bregðast við, bæði í stefnumótun og pegar ákvarðanir eru teknar um daglegt skólastarf.

\section{Nokkur leiðarstef við innleiðingu menntaumbóta}

Með hliðsjón af peirri pekkingu sem dregin hefur verið saman hér að framan eru sett fram sjö leiðarstef sem hugsuð eru sem nokkurs konar leiðarvísir fyrir pá sem leiða umbætur menntakerfa, skóla eða í bekkjardeild. Dau ber ekki að líta á sem lista yfir aðgerðir sem má velja úr eða hafna, heldur miklu fremur gagnlegar ábendingar sem leiðarljós við innleiðingu á hverju og einu umbótaverkefni sem ráđist er í. Pau eru sett fram af virðingu fyrir flóknum veruleika skóla og menntakerfa og byggja á umbótamiðaðri nálgun (Forde og McMahon, 2019; Gunter o.fl., 2016; Robinson, 2018) sem leggur áherslu á samvirkni og faglegt nám sem lykil að gæðamenntun og par með betri árangri.

1. Áhersla á nám og kennslu ætti að vera skýr í öllum ákvörðunum, m.a. um stefnu, aðgerðir og starfspróun. Mestu skiptir að öll börn í íslensku menntakerfi eigi kost á merkingarbæru námi sem stundað er í proskavænlegum aðstæðum og að pau nái framförum á eigin forsendum. Hlúa parf að pví starfi sem fer fram í samskiptum nemenda og kennara, í skólastofum eða í deildum pví par fer hin eiginlega innleiðing umbóta fram. Á öllum stigum parf að spyrja hverju áætlaðar breytingar (eða óbreytt ástand) skili til nemenda.

2. Aðstæðubundnar aðgerðir sem miðast við veikleika og styrkleika á hverjum stað, á hverju sviði eða í hverjum skóla. Breytingastarf kostar oft og tíðum mikla orku, tíma og fjármagn og pví er nauðsynlegt að aðgerðir séu markvissar og byggi á ígrundun áreiðanlegra gagna Pótt meðaltöl gefi mikilvægar upplýsingar eru pau ekki endilega góður grunnur að ákvörðunum, par sem pau gefa tilefni til alhæfinga og aðgerðir eru látnar ganga yfir alla hvort sem pörf er á peim eða ekki. Niðurstöður rannsókna og prófa eða önnur gögn ættu að vera rýnd af peim sem starfa í viðkomandi aðstæðum og ákvarðanir um aðgerðir teknar af peim en með hliðsjón af sampykktri stefnu. Með hliðsjón af ábendingum Robinson (2018) purfa yfirvöld að vanda til verka pegar gerðar eru kröfur um breytingar.

3. Samstarfsmiðuð nálgun og samvirkni ætti að einkenna alla viðleitni til umbótastarfs, í skólakerfinu öllu, milli skólastiga og stofnana jafnt sem innan hvers skóla eða sviðs Samstillt átak parf til að próa gott menntakerfi, pað gerir enginn einn, hvorki einstaklingur né stofnun. Samvirkni og sameiginlegur skilningur næst 
best með virku samstarfi og samræðu um stefnu og aðgerðir í námi og kennslu. Af pessu ætti að taka mið t.d. við ákvarðanatöku, markmiðssetningu, hlutverkaskipan og gerð verkferla.

4. Áhersla á að styrkja faglega forystu, pekkingu og hæfni peirra sem starfa í menntakerfinu, einkum kennara og stjórnenda, og byggja upp hæfni til stöðugra umbóta. Pótt kennarar og stjórnendur séu í brennidepli á petta einnig við um aðra sem starfa í skólakerfinu, svo sem á skólaskrifstofum, í kennaramenntun, hjá Menntamálastofnun, hjá Kennarasambandinu eða öðrum peim samtökum og stofnunum sem bera ábyrgð á gæðum menntunar. Öll umbótaverkefni, bæði stór og smá, purfa öflugt utanumhald og skýra faglega forystu sem fer ekki eingöngu fram miðlægt. Раð parf að tryggja faglega forystu á öllum stigum og efla leiðtogahæfni margra.

5. Efla fjölbreyttar rannsóknir sem beinast að námi og kennslu, nýta hlutlæg gögn til að fylgjast með framförum nemenda og efla faglegt nám starfsfólks. Í pessu felst m.a. efling vísindasamfélagsins til að vinna umfangsmeiri rannsóknir og samstarfsrannsóknir vísindafólks og kennara. Ekki er síður mikilvægt að styrkja kennara og stjórnendur skóla til að vinna og nýta rannsóknir og hlutlæg gögn í daglegu starfi sem nefna má rannsóknarmiðaða fagmennsku.

6. Áhersla á foreldra sem samstarfsaðila í skólastarfi og sterkustu áhrifavalda á námsárangur og vellíðan barna sinna. Petta snýr ekki eingöngu að skólum heldur að samfélaginu öllu, velferðarpjónustu, frístundastarfi og atvinnulífi. Meðal annars parf að styrkja fjölskyldur í uppeldishlutverkinu og vinna gegn fátækt barna. Starfsfólk sveitarfélaga og skóla gæti í ríkari mæli en nú er leitað leiða til að virkja foreldra.

7. Síðast en ekki síst er ítrekuð áhersla á leiðir til að stuðla að jöfnuði og er pá einkum bent á ráðleggingar JustEd (2018) sem beinast að áherslum og aðgerðum stjórnvalda bæði á landsvísu og innan sveitarfélaga en ekki síður að einstökum skólum par sem parf að ríkja jöfnuður.

Til að útskýra nánar hvernig pessi leiðarstef gætu nýst er hér tekið eitt dæmi par sem horft er til peirra allra. Niðurstöður PISA 2015 (Menntamálastofnun, 2017) í læsi benda til að íslenskir nemendur standi sig ekki vel í að meta, túlka eða ígrunda upplýsingar í texta eða að draga ályktanir út frá honum. Detta atriði beinist ekki eingöngu að læsi eða íslenskukennslu heldur að öllu námi. Dví liggur beint við að skoða hvernig vitsmunaleg áskorun barna birtist í námi peirra og daglegu lífi, hvort pau séu að glíma við viðfangsefni sem eru líkleg til að proska vitsmunalega hæeni peirra. Áhersla ætti að beinast að kennsluháttum og námsefni í öllum námsgreinum sem og í kennaramenntun og starfspróun kennara. Stuðningskerfi skólanna ætti að leggja áherslu á að hafa tiltæk verkfæri til að aðstoða kennara og stjórnendur við að greina vitsmunalega áskorun í námi og kennslu á öllum aldursstigum. Rannsakendur ættu einnig að koma til aðstoðar og beina sjónum sínum að pessu viðfangsefni. Foreldrar og reyndar samfélagið allt ætti að huga að hvers konar viðfangsefni börnin fást við í frítíma sínum, hvernig samræður pau eiga við fullorðna, hvaða myndefni pau horfa á og hvað fjölskyldan gerir saman. Dá parf að huga að pví hvaða viðfangsefni eru í boði í frístundastarfi, hvernig aðgengi barna er að tónlistarnámi, bókum, leikhúsum og svo framvegis. Síðast en ekki síst eiga áherslur að beinast að pví að allir nemendur glími við áskoranir sem hæfa peirra getustigi par sem árangur er mældur í framförum peirra sjálfra fremur en stöðluðum viðmiðum og stuðla pannig að jöfnuði. 


\section{Að lokum}

Góður skóli verður ekki til vegna pess hvað hver og einn einstaklingur gerir, heldur pess sem hópurinn gerir, með samvirkum aðferðum kennara, stjórnenda, yfirvalda og annarra sem koma að skólastarfinu. Að sama skapi verður ekki til gott menntakerfi nema allir leggjast á eitt og vinni saman og af fagmennsku á öllum stigum kerfisins. Líta ber á kennara og skólastjórnendur sem mótendur og pátttakendur í ákvarðanatöku og gagnrýninni umræðu en ekki eingöngu gerendur sem taka við markmiðum til að útfæra í daglegu starfi. Detta sjónarmið kallar meðal annars á endurskoðun á pví hvað felst í fagmennsku kennara og stjórnenda. Eitt af brýnustu viðfangsefnum 1 íslensku menntakerfi er að efla traust og styrkja fagmennsku á öllum stigum kerfisins. Engin leið er að vita nákvæmlega hverjar eru ástæður fyrir slakri útkomu íslenskra unglinga í PISA, pær geta legið í ákvörðunum sem voru teknar eða ekki teknar fyrir löngu síðan. Ekki er heldur hægt að segja til um hvort aðgerðir sem gripið hefur verið til síðan 2015 hafi skilað árangri eða ekki, mögulega hefur eitthvað sem ekki var gert eða gert ranglega spillt fyrir árangri. Dví pjónar pað ekki tilgangi að leita sökudólga. Líta parf fram á veginn, greina veikleika og styrkleika menntakerfisins út frá breiðu sjónarhorni, viðurkenna stöðuna og taka stefnuna paðan, með hag allra barna að leiðarljósi og með hugsjón um jöfnuð, faglega pekkingu og hæfni í farteskinu.

\section{After PISA. A few guidelines on implementation of educational improvements}

The results of PISA 2018 will be published in early December 2019. Based on experience, extensive discussions are expected regarding the quality or even lack of quality in the Icelandic school system. The purpose of this article is to contribute to these discussions, particularly in regard to what might constitute suitable reactions or future actions to improve the quality of education for Iceland's children and young people. Recent research on the characteristics of successful educational improvements is summarised, and attempts are made to shed light on what practical implications these may have for the implementation of educational improvements. Based on this knowledge, seven guidelines are outlined for those planning and leading educational improvements at the levels of system, school and classroom. These should not be seen as a list of actions to be taken, but rather as tips to guide the implementation of each and every improvement project undertaken. The guidelines are presented with respect for the complex reality of schools and the educational system, and they focus on coherence, a collaborative approach, and professional learning as keys to increasing the quality of education (e.g., Fullan \& Quinn, 2016; Fullan \& Hargreaves, 2016; Hopkins et al., 2014; Robinson, 2018).

The guidelines are as follows:

1. All decisions should have a clear focus on teaching and learning, including policy, projects, and professional learning activities. The work that takes place in communication between students and teachers, whether in classrooms or in departments, must be nurtured because that is where the actual implementation of reforms takes place. At all stages in a change process, questions should be posed about the effect such changes will have on children.

2. Actions taken in each situation should be based on measurements at each location and directed towards a targeted group of students. Change requires much investment of energy, time, and resources, and therefore actions need to be targeted and based on reliable data. Averaged measures are not necessarily an appropriate or useful basis for decision making, as they may lead to generalisations. The results of research, tests, or other data should be reviewed 
by those in the relevant situation, and decisions should be made by them. Given Robinson's (2018) suggestions, authorities need to be careful when making recommendations for changes.

3. Coherence and a collaborative approach should characterise all improvement efforts. Coherence and shared understanding are best achieved through active collaboration and dialogue on policies and actions. This should be considered, e.g., in decision making, goal setting, assignment, and process making.

4. Building capacity for continuous improvement is achieved through focus on professional learning and leadership by those working in the system, especially teachers and leaders. But this also applies to those who work at other levels such as in school offices, teacher education, the Institute of Education, the teachers' union, and in other organizations and institutions responsible for the quality of education. All improvement projects, both large and small, require strong professional leadership that is distributed and not merely centralised.

5. Evidence informed policy, practice, and professional learning and researchfocused professionalism are key concepts. This includes, for example, strengthening the research community to undertake more extensive studies and form collaborations between educational researchers and practitioners.

6. Parents should be acknowledged as active collaborators and those who have the strongest influence on educational achievement and the well-being of their children. This is not merely about schools, but also about society, welfare services, leisure, and business. Among other things, families need to be strengthened as to the role of parenting. Special care should be taken with children and families in vulnerable situations.

7. Last but not least, a clear equity stance should be taken in policy and practice at all levels, for example in policies at national and local levels and in practice at school and classroom levels. JustEd (2018) suggestions are useful in this matter.

A sound education does not rely on the actions or efforts of individuals; it is a collective endeavour relying on dialogue and collaboration between teachers, leaders, authorities, and others in the educational system. Teachers and school leaders should be seen as active participants in decision making, not merely as those who implement pre-determined plans. One of the most important challenges in the Icelandic educational system is to build trust and strengthen professionalism at all levels.

Key words: Educational improvements, Implementation, Coherence, Professional learning community, Quality of educational system, Educational research

\section{Um höfund}

Anna Kristín Sigurðardóttir aks@hi.is er prófessor við Menntavísindasvið Háskóla Íslands og formaður námsbrautar um menntastjórnun og matsfræði. Hún er með B.Ed.-gráđu í grunnskólakennslu og M.Ed.-gráđu frá Kennaraháskóla Íslands í sérkennslu. Doktorsgráđu lauk hún frá Háskólanum í Exeter 2006 á sviði skólapróunar og menntastjórnunar. Rannsóknarsvið hennar tengjast menntastjórnun og menntaumbótum, lærdómssamfélagi og námsumhverfi skóla í tengslum við nám og kennslu. 


\section{About the author}

Dr. Anna Kristín Sigurðardóttir aks@hi.is is a professor at the University of Iceland, School of Education. She is currently head of department for educational leadership and school evaluation. She holds a B.Ed. in teaching, an M.Ed. in special education and a Ph.D. from the University of Exeter, UK, in educational development and leadership. Her research interests concern systemic and school development, leadership, the professional learning community and the link between space and teaching and learning.

\section{Heimildir}

Anna Kristín Sigurðardóttir. (2008). Faglegt samstarf kennara. Glæður. Fagtímarit félags íslenskra sérkennara, 18, 13-19.

Anna Kristín Sigurðardóttir. (2010). Professional learning community in relation to school effectiveness. Scandinavian Journal of Educational Research, 54(5), 395-412. doi: 10.1080/00313831.2010.508904

Anna Kristín Sigurðardóttir. (2013). Skóli sem lærdómssamfélag. Í Rúnar Sigpórsson, Rósa Eggertsdóttir og Guðmundur Heiðar Frímannsson (ritstjórar), Fagmennska í skólastarfi. Skrifað til heiðurs Trausta Dorsteinssyni (bls. 35-53). Reykjavík: Háskólaútgáfan.

Anna Kristín Sigurðardóttir, Morris, A., Skoglund, P. og Tudjman, T. (2018). Knowledge partnerships between schools and universities: Modelling the process of connection and relations. Evidence \& Policy: A Journal of Research, Debate and Practice, 14(4), 683-705. doi:10.1332/174426417X14872517690770

Ash, R. C. og Hodge, P. H. (2016). Five critical leadership practices. The secret to high performing schools. New York: Routledge.

Asia Society, Centre for Global Education. (2011). Improving teacher quality around the world: The international summit on the teaching profession. Sótt af https://asiasociety.org/education/improving-teacher-quality-around-world

Barber, M. og Mourshed, M. (2007). How the world's best performing school systems come out on top. New York: McKinsey \& Company.

Berglind Gísladóttir,Auður Pálsdóttir, Anna Kristín Sigurðardóttir og Birna Svanbjörnsdóttir. (bíður útgáfu. Mat á stöðu faglegs lærdómssamfélags í grunnskóla. Dróun mælitækis. Netla-Veftímarit um uppeldi og menntun.

Berglind Gísladóttir, Hans Haraldsson og Amalía Björnsdóttir. (2019). Samband menntunar foreldra við frammistöðu pátttakenda í PISA-könnuninni á Norðurlöndum. Sérrit Netlu 2019-Alpjóðlegar menntakannanir. Sótt af http://netla.hi.is/serrit/2019/altjodlegar_menntakannanir/03.pdf

Berglind Rós Magnúsdóttir og Auður Magndís Auðardóttir. (2019). Aukin aðgreining milli skólahverfa út frá efnahag, uppruna og menntun foreldra: Dróun á höfuðborgarsveeðinu 1997-2016 [erindi flutt á opinni málstofu á vegum Rannsóknarstofu um próun skólastarfs, 31. janúar 2019].

Blossing, U., Nyen, T., Söderström, A. og Tønder, A. H. (2015). Local drivers for improvements capacity. Six types of school organisations. Heidelberg: Springer.

Boylan, M. og Demack, S. (2018). Innovation, evaluation design and typologies of professional learning. Educational Research, 60(3), 336-356. doi: 10.1080/00131881.2018.1493352

Burns, M. K., Naughton, M. R., Preast, J. L., Wang, Z., Gordon, R. L., Robb,V. og Smith, M. L. (2017). Factors of professional learning community implementation and effect on student achievement. Journal of Educational and Psychological Consultation, 28(4), 394-412. doi:10.1080/10474412.2017.1385396

Buttram, J. L. og Farley-Ripple, E. N. (2016). The role of principals in professional learning communities. Leadership and Policy in Schools, 15(2), 192-220. doi: 10.1080/15700763.2015.1039136

Cowan, D., Joyner, S. og Beckwith, S. (2012). Getting serious about the system. California: Corwin.

Darling-Hammond, L. (2013). Getting teacher evaluation right. What really matters for effectiveness and improvements. New York: Teachers College Press. 
Dogan, S. og Adams, A. (2018). Effect of professional learning communities on teachers and students: Reporting updated results and raising questions about research design. School Effectiveness and School Improvement, 29(4), 634-659. doi:10.1080/09243453.2018.1500921

Dovemark, M., Kosunen, S., Kauko, J., Magnúsdóttir, B. R., Hansen, P. og Rasmussen, P. (2018). Deregulation, privatisation and marketisation of Nordic comprehensive education: Social changes reflected in schooling. Education Inquiry, 9(1), 122-141. doi:10.1080/20004508.2018.1429768

Forde, C. og McMahon, M. (2019). Teacher quality, professional learning and policy. Recognising, rewarding and developing teacher expertise. London: Palgrave Macmillan.

Fullan, M. (2016). The new meaning of educational change (5. útgáfa). New York: Teachers College Press.

Fullan, M. og Hargreaves, A. (2016). Bringing the profession back in. Call to action. Sótt af https://learningforward. org/docs/default-source/pdf/bringing-the-profession-back-in.pdf

Fullan, M. og Quinn, J. (2016). Coherence. The right drivers in action for schools, districts and systems. Thousand Oaks, CA: Corwin.

Gerður G. Óskarsdóttir (ritstjóri). (2014). Starfshættir í grunnskólum við upphaf 21. aldar. Reykjavík: Háskólaútgáfan.

Gerður G. Óskarsdóttir og rannsóknarhópur um starfshætti í framhaldsskólum. (2018). Starfshættir í framhaldsskólum: Aðdragandi og framkvæmd rannsóknar 2012-2018. Sérrit Netlu 2018 - Framhaldsskólinn í brennidepli. Sótt af http://netla.hi.is/serrit/2018/framhaldskolinn_brennidepli/01.pdf

Grandemo, L. I., Holmen, H. K. og Iversen, K. (2017).Vi er ikke alene om utfordringene lenger. Kollegaobservasjon som utviklingsverktøj. Í M. B. Postholm o.fl. (ritstjórar), Ungdomstrinn í utvikling. Skoleutvikling og ledelse (bls. 78-98). Oslo: Universitetsforlaget.

Gunter, H. M., Grimaldi, E., Hall, D. og Serpieri, R. (2016). New public management and the reform of education: European lessons for policy and practice. New York: Routledge.

Hairon, S., Goh, J.W. P., Chua, C. S. K. og Wang. L. (2017). A research agenda for professional learning communities: Moving forward. Professional Development in Education, 43(1), 72-86. doi:10.1080/19415257.2 015.1055861

Hanna Ragnarsdóttir. (2016). Námsrými félagslegs réttlætis og menntunar án aðgreiningar: Niðurstöður norrænnar rannsóknar um velgengni nemenda af erlendum uppruna og skóla á fjórum Norðurlöndum. Sérrit Netlu 2016 - Námsrými félagslegs réttlatis og menntunar án aðgreiningar. Sótt af http://netla.hi.is/ serrit/2016/namsrymi_felagslegs_rettlaetis_og_menntunar_an_adgreiningar_learning_spaces_for_inclusion_and_social_justice/001.pdf

Hargreaves, A. og Shirley, D. (2013). The global fourth way. The quest for educational excellence. Thousand Oaks, CA: Corwin.

Hargreaves, A. og Fullan, M. (2012). Professional capital. Transforming teaching in every school. New York:Teachers College Press.

Harris, A. (2012). Leading system-wide improvements. Leadership in Education, 15(3), 395-401. doi:10.1080 /13603124.2012.661879

Harris, A. (2013). Building the collective capacity for system change: professional learning communities in Wales. Í H.J. Malone (ritstjóri), Leading educational change. Global issues, challenges and lessons on whole-system reform (bls. 109-113). New York: Teachers College Press.

Harris, A. og Jones, M. (2010). Professional learning community and system improvement. Improving Schools, 13(2), 172-181. doi: 10.1177/1365480210376487

Hatch, T. (2013). Beneath the surface of accountability: Answerability, responsibility and capacity building in recent educational reform in Norway. Journal of Educational Change, 14(2), 113-138. doi:10.1007/ s10833-012-9206-1

Hopkins, D., Stringfield, S., Harris, A., Stoll, L. og Mackay, T. (2014). School and system improvement: A narrative state-of-the-art review. School Effectiveness and School Improvement, 25(2), 257-281. doi: 10.1080/09243453.2014.885452

Ingvar Sigurgeirsson og Ingibjörg Kaldalóns. (2017). Er samvinna lykill að skólapróun? Samanburður á bekkjarkennsluskólum og teymiskennsluskólum. Netla - Veftímarit um uppeldi og menntun. Sótt af http:// netla.hi.is/greinar/2017/ryn/10.pdf 
Jensvoll, M. H. og Lekang,T. (2017). Kollektiv profesjonsutvikling med fokus på lærerens læring. Í M. B. Postholm o.fl. (ritstjórar), Ungdomstrinn í utvikling. Skoleutvikling og ledelse (bls. 59-77). Oslo: Universitetsforlaget.

Jón Torfi Jónasson. (2016). Educational change, inertia and potential futures: Why is it difficult to change the content of education? European Journal of Futures Research, 4(7). doi:10.1007/s40309-016-0087-z

JustEd [Nordic Centre of excellence, Justice through education in the Nordic countries]. (2018). 3 leiðir til að efla jöfnuð og réttlati í norrænum skólum og kennslustofum. Sótt af https://issuu.com/equaleducation/ docs/is_issue

Kolbeinn H. Stefánsson. (2019). Lífskjör og fátækt barna á Íslandi 2004-2016. Skýrsla unnin fyrir Velferðarvaktina. Sótt af https://www.samband.is/media/uncategorized/Lifskjor_fataekt_barna_2004-16-lokaeintak-27.2.2019.pdf

Kristján Jóhann Jóhannson og Ásgrímur Angantýsson. (2018). Íslenska í grunnskólum og framhaldsskólum. Reykjavík: Háskólaútgáfan.

Kristján Kristjánsson. (2019). Flourishing as the aim of education. A neo-Aristotelian view. Abington, Oxon: Routledge.

Labaree, D.F. (2010). Someone has to fail. The zero-sum game of public schooling. Cambridge USA og London UK: Harvard University Press.

Lomos, C., Hofman, R. H. og Bosker, R. J. (2011). Professional communities and student achievement: A meta-analysis. School Effectiveness and School Improvement, 22(2), 121-148.

McLaughlin, M.W. og Talbert, J. E. (2001). Professional communities and the work of high school teachers. Chicago: The University of Chicago Press.

Menntamálastofnun. (2017). Helstu niðurstöður PISA 2015. Reykjavík: Höfundur.

Mortimore, P., Sammons, P., Stoll, L., Lewis, D. og Ecob, R. (1988). School matters. The junior years. Somerset: Open Books.

Muijs, D., Kyriakides, L., van der Werf, G., Creemers, B., Timperley, H. og Earl. L. (2014). State of the art teacher effectiveness and professional learning. School Effectiveness and School Improvement, 25(2), 257-281. doi: 10.1080/09243453.2014.885451

Murray, J. (2014). Designing and implementing effective professional learning. Thousand Oaks, CA: Corwin.

OECD. (2012). Equity and quality in education. Supporting disadvantaging students and schools. París: Höfundur.

Robinson, V. (2018). Reduce change to increase improvement. London: Corwin.

Robinson, V., Bendikson, L., McNaughton, S., Wilson, A. og Zhu, T. (2017). Joining the dots: The challenge of creating coherent school improvement. Teachers College Record, 119(9), 1-44.

Rúnar Sigpórsson og Gretar L. Marinósson (ritstjórar). (2017). Byrjendalasi: Rannsókn á innleiðingu og aðferð. Reykjavík: Háskólaútgáfan og Háskólinn á Akureyri.

Rúnar Sigpórsson og Rósa Eggertsdóttir. (2008). Skólapróun og skólamenning. Í Loftur Guttormsson (ritstjóri), Alpýđufraesla á Íslandi 1880-2007: Síðara bindi (bls. 294-311). Reykjavík: Háskólaútgáfan.

Sarason, S. B. (1971). The culture of the school and the problem of change. Boston: Allyn and Bacon.

Schildkamp, K., Ehren, M. og Lai, M. K. (2012). Editorial article for the special issue on data-based decision making around the world: From policy to practice to results. School Effectiveness and School Improvement, 23(2), 123-131. doi: 10.1080/09243453.2011.652122

Snædís Valsdóttir. (2017). Notkun gagna í próun skólastarfs í grunnskólum (óútgefin meistararitgerð). Menntavísindasvið Háskóla Íslands, Reykjavík.

Spillane, J. P. (2012). Data in practice: Conceptualizing the data-based decision-making phenomena. American Journal of Education, 118(2), 113-141. doi: 10.1086/663283

Steiner-Khamsi, G. (2013). What is wrong with the 'What-Went-Right' approach in educational policy? European Educational Research Journal, 12(1), 20-41. doi:10.2304/eerj.2013.12.1.20

Stoll, L., Bolam, R., McMahon, A., Wallace, M. og Thomas, S. (2006). Professional learning communities: A review of the literature. Journal of Educational Change, 7(4), 221-258.

Stoll, L., Harris, A. og Handscomb, G. (2012). Great professional development which leads to great pedagogy: Nine claims from research. Sótt af https://www.appa.asn.au/wp-content/uploads/2015/08/stoll-article2.pdf 
Stoll, L. og Louis, K. S. (ritstjórar). (2007). Professional learning communities: Divergence, depth and dilemmas. Maidenhead, UK: Open University Press.

Stjórnarráð Íslands og Mennta- og menningarmálaráðuneytið. (2019). Samstarfsráð um starfspróun kennara og skólastjórnenda. Skýrsla til mennta- og menningarmálaráðherra. Sótt af https://www.stjornarradid.is/lisalib/ getfile.aspx?itemid=349b2e00-ef44-11e9-944e-005056bc530c

Supovitz, J.A. og Tognatta, N. (2013). The impact of distributed leadership on collaborative team decision making. Leadership and Policy in Schools, 12(2), 101-121.

Teddlie, C. og Stringfield, S. (1993). Schools make a difference. Lessons learned from a ten-year study of school effects. New York: Teachers College Press.

Trippestad, T. A. (2017). The visionary position: Critical factors in utopian social engineering in educational reforms. London: Bloomsbury Academic.

Tyack, D. og Cuban, L. (1995). Tinkering toward utopia: A century of public school reform. Cambridge, MA: Harvard University Press.

Wennergren, A. C. (2015). Teachers as learners - with a little help form a critical friend. Educational Action Research, 24(2), 260-279. doi:10.1080/09650792.2015.1058170

Anna Kristín Sigurðardóttir. (2019).

PISA - Hvað svo? Nokkur leiðarstef um innleiðingu menntaumbóta

Netla - Veftímarit um uppeldi og menntun. Menntavísindasvið Háskóla Íslands.

Sótt af http://netla.hi.is/serrit/2019/altjodlegar_menntakannanir/04.pdf

DOI: https://doi.org/10.24270/serritnetla.2019.42 